\title{
A Two-Dimensional Framework for RFID Adoption and Diffusion: Strategic Implications for Developing Countries
}

\author{
Nyoman Adhiarna',Yoon-Min Hwang' ${ }^{2}$,jae-Jeung Rho
}

\begin{abstract}
Although there has been a growing interest in studying RFID in various application areas, little research has been undertaken to address applications in developing countries. Among the research that has been undertaken in developing countries, organizational perspectives have received considerable attention but less has been undertaken from other perspectives such as industry and country level. In this paper, a literature study of RFID adoption from different perspectives is presented and focuses on the stages of adoption, level of analysis, and issues of developing countries. A stage-scale (2S) framework is proposed to help identify relevant success factors in RFID adoption and diffusion, as well as its relation to other factors. It is concluded that the proposed framework is useful in providing a broad view of RFID adoption and in observing the dynamic changes in RFID issues from different stages, which is useful for policy and decision makers. Based on this framework, most factors of RFID adoption in developing countries fall within the preliminary stage, while the factors that are shared with developed countries are mostly situated in intermediate stages.
\end{abstract}

Keywords: RFID adoption; success factors; IT adoption; developing countries; level of analysis; stages of adoption.

\footnotetext{
' Global Information \& Telecommunication Technology Program, IT Convergence Campus, Korea Advanced Institute of Science and Technology (KAIST), I 19 Munji-ro, Yuseoung-gu, Daejeon 305-732, Republic of Korea. Telp. +82-42-350-6845. Fax. +82-42-350-6858. Email: adhiarna@kaist.ac.kr;adhiarna@yahoo.com

${ }^{2}$ Department of Management Science, Korea Advanced Institute of Science and Technology (KAIST), 29I Daehak-ro (373-I Guseong-dong), Yuseong-gu, Daejeon 305-70 I, Republic of Korea. Tel . +82-42-350-2 I I 4. Fax . +82-42-350-2210 (2220). Email:ymhwang@kaist.ac.kr;jirho@kaist.ac.kr.
} 


\section{Introduction}

Radio frequency identification (RFID) is currently regarded as one of the most promising auto-identification and data capture technologies (OECD, 2007). This technology works using a concept similar to barcoding but it utilizes the advantages of wireless technology, allowing automated data identification and wirelessly capturing tagged objects without need for contact or direct line of sight. RFID is perceived as a critical technology for various purposes and applications such as improving the efficiency and effectiveness of supply chains, improving security in business operations, and providing better customer service. In today's business, all of these advantages would dramatically impact a firm's business operations through the improvement of efficiency and effectiveness in production and operation, as well as providing better service to customers (Irani et al., 2010). In terms of pervasiveness, commercial availability, and market demand, RFID is projected to be one of the sixteen key technologies in coming decade (Silberglitt et al., 2006). Pervasive RFID adoption and diffusion in the future by the extensive uses of inexpensive tags will realize the notion of what many scholars envisage as "Internet of things" which merges online worlds with objects in the real world (Slettemeås, 2009).

RFID adoption and diffusion in diverse situations have been extensively studied in recent years by many researchers but few specifically address issues in developing countries. Logistics and supply chains are generally regarded as leading examples of RFID applications by many studies in private organizations (Fish and Forrest, 2007; Chao et al., 2007). Meanwhile, public transportation, healthcare, and government identification are primary examples of applications in public sectors. Since most RFID pilot projects and settings are established in developed or industrialized countries, it is not surprising that most studies on RFID adoption discuss those cases in developed country. Some regional organizations from developed countries, such as the EU and OECD, have published various periodical reports on RFID projects from their respective member countries, which increase the gap in the literature with regards to developing countries. Recently, a few studies have been conducted in developing countries; some studies have pioneered research that directly addresses the issues of developing countries such as issues of retail (Brown and Russell, 2007) and national perspectives (Lai et al., 2005).
Currently, most studies on RFID adoption focus on organizations or companies with issues including adoption and implementation, organizational determinants, drivers and benefits, and challenges to adoption. Organizations and companies are usually considered because the adoption of RFID technology begins with a closed loop (single organization) and is generally easier to observe at this level. However, from a level of analysis perspective, few studies have discussed adoption from higher levels of analysis such as industry or country levels. As the cost of RFID will decrease significantly as the technology develops and becomes more affordable for organizations and industries in developing countries, it is expected that a wide range of applications for RFID in developing countries is imminent. Thus, studying RFID adoption in developing countries from a country perspective or industry perspective is very important for policy makers and business decision makers. Some literature has concluded that there is great importance placed on the government in facilitating successful implementation of RFID in targeted areas of applications such as in the military, environment, personal identification (such as e-passports), healthcare services, public transport fare collection systems, education and cultural institutions (e.g. museums and libraries), and cell phone based applications (see OECD, 2008; Edwards, 2007 and 2009; Fish and Forrest, 2007).

Much literature on RFID adoption is based on well-known frameworks that originated from other areas of research such as innovation or information systems. Among the literature, there are several well-known theories and their adaptations are applied generally, such as diffusion of innovation (Lin, 2008; Sharma et al., 2008; Wen et al., 2004), technology acceptance model (TAM) (Hossain and Prybutok, 2008), technology, organization and environment (TOE) (Schmitt and Michahelles, 2007), as well as other information technology (IT) adoption theories. Most existing RFID research, particularly for developed countries, has been dominated by organizational, behavioral, and information system perspectives (Slettemeås, 2009).

As most literature specifically addresses the issues present in developed countries, it would be of interest to study the factors of RFID adoption and diffusion in developing countries from various perspectives. Therefore, understanding the factors that drive RFID adoption and diffusion is a critical step in understanding 
the policy or business decisions required for its successful implementation. In this paper, a literature study of RFID adoption from different perspectives, particularly from different levels of analysis and stages of adoption, is presented. Based on these perspectives, a framework to identify RFID success factors in developing countries is proposed.

\section{Literature Review on RFID Adoption}

RFID adoption can be viewed from different perspectives and in this paper three categories are targeted: level of analysis, stages of RFID adoption, and national development perspectives. Currently, there are many theories and frameworks applied in RFID adoption and diffusion from perspectives based on information system and innovation system theories. Unfortunately, none of the studies directly address study of RFID adoption at country and industry levels although there is much research on IT adoption at this level of analysis. Studies at the industry level are generally discussed as a part of an organizational perspective, but none discuss specific frameworks or theories at this level. Furthermore, in the adoption stage, there is a lack of theories and conceptual frameworks being proposed for RFID adoption even though there are many theories and conceptual frameworks devised for IT adoption and diffusion.

\section{I. Stages of RFID Adoption and Diffusion}

Among the literature available, few conceptual and empirical research studies have been undertaken in the RFID stages of adoption. The Diffusion of Innovation (DOI) theory proposed by Rogers (1983) is regarded as the foundation of much literature in IT adoption; furthermore, this theory is the most referred theory in IT adoption due to its well-developed concepts and large number of empirical results (Schmitt et al., 2009). Beyond the welldeveloped theory of DOI, much literature discusses the adoption and diffusion of IT in different levels of analysis from country level to organizational level. Some literature has similar intentions of proposing stages of IT adoption and diffusion. Nolan and Benjamin (1973), who applied an early model of IT adoption at an organizational level, proposed a framework of IT adoption based on the IT spending of an organization which consisted of several stages: initiation, contagion, control, integration, data administration, and maturity. Nolan and Benjamin assumed that the changes in IT spending can reflect a surrogate measure for environmental and technical variables. Based on Nolan and Benjamin's approach to an organization's IT spending, Guo and Chen (2005) investigated patterns of Internet adoption in Chinese companies based on four stages: initiation, contagion, cooling, and permeation. From an organizational perspective, McKay et al. (2000) proposed eBusiness stages of growth that consider the impact of the Internet as an inter-organizational system for e-business maturity. This model describes the increasing maturity of Internet uses, which parallels the sophistication of newer technologies and systems.

From the perspective of IT adoption in a country, the OECD (1999) conducted a study of IT adoption patterns to identify relevant measures for eCommerce growth and the patterns consisted of three stages: the readiness stage which focuses on enabling factors of and barriers to growth; the intensity stage which focuses on the intensity of the growth; and the impact stage which focuses on non-quantitative measures and the impact of eCommerce on the economy and society. Based on the OECD study, Corrocher and Ordanini (2002) developed a framework for the stages of a digital economy that is measured from a country's level of digitalization. According to this model, there are three stages of digitalization: the speed of adoption stage which focuses on the uses and applications of IT; the intensity stage which focuses on the diffusion of devices and the size of digital markets; and the impact stage which focuses on the social and economic activities of IT.

However, for RFID adoption and diffusion, few conceptual studies directly address issues of RFID adoption stages and some literature is primarily based on practical observations. For example, Chao et al. (2007) proposed the stages of RFID technological development covering three stages: Stage I which focuses on tag innovation including data communication and access control, Stage 2 which covers tag applications; and Stage 3 which discusses the system applications of RFID for tracking goods or objects. In addition, White et al. (2004) identified three stages of adoption from early to final stages that cover an elementary stage which focuses on ensuring nominal compliance, an intermediate stage which focuses on creating process efficiency and better value, and a final stage which focuses on widespread adoption and better understanding of the changes in customer demands. 


\subsection{Levels of Analysis on RFID Adoption and Diffusion}

Although the determinants of RFID adoption have been studied extensively in recent years from different perspectives, most literature has focused on organizational levels or a combination between organization and mesomacro-environment perspectives. Few studies have focused directly on industry or country level perspectives. Currently, there much literature that studies IT adoption at a country level, but none discuss specific frameworks for RFID adoption. Studies of IT adoption are generally characterized by diverse research goals and topics that involve different factors, weights, and interpretations although they may employ the same framework. Some studies have a strong focus on IT infrastructure and others focus on user issues, which result in different assessment and outcomes. Maugis et al. (2005) argued that the framework should not be designed as a one-size-fits-all due to the nature of ICT, different countries' characteristics, and the nature of applications: rather it should be able to reflect the uniqueness of these factors. Thus, identifying and selecting critical factors are a research challenge in creating an IT adoption and diffusion framework.

There is a variety of literature that studies country level IT adoption and many frameworks have been developed based on specific issues. Some popular issues are the digital divide and eReadiness. Kauffman and Techatassanasoontorn (2005) studied factors for the global digital divide for wireless phone technologies which were categorized into within country factors (e.g. wealth, telecom infrastructure, market competition, access cost, access standards) and geographical influences (regional influences, international influences). Di Gregorio et al. (2005) in their study on drivers of eBusiness activity concluded that ICT infrastructure, human capital, institutional environment, path dependence, entrepreneurial activity, and regional difference were dominant factors influencing IT adoption. Dewan et al. (2005) investigated factors influencing the digital divide which were categorized into economic (GDP, technology cost), demographic (urban population), and environmental (telephone lines, trade in goods) factors. Shih et al. (2008) concluded that in terms of IT diffusion, which is measured by IT investment in developing countries, there are three core factors that influence the digital divide: capital resources, complementary assets (infrastructure and human resources), and openness to external influence. The authors argued that the effective use of IT requires external influences in the forms of technical and managerial knowledge, foreign trade, and foreign investment, which ensure cross-border learning and affect technical progress in the target country.

Similar to country level, little attention has been paid to studies of RFID adoption at industry level. Some factors that belong to the industry level, such as industry standards, industry association, and market size, are generally categorized into environmental factors in organizational level studies. Porter's popular five competitive force model is commonly used for IT industry analyses (as in Haghighi et al., 2010; White et al., 2007). In this model, critical factors are extracted from competitive forces such as competitors, customers, and technology suppliers. One of the most comprehensive studies of RFID adoption at industry level was conducted by the OECD and the report concluded that there are four common factors that exist for RFID adoption across industry: standards, business benefit, application stage, and technology level (OECD, 2007). For early adopters, factors such as anticipated benefits, anticipated ROls, and decision to adopt are issues that should be considered for RFID adoption at industry level (White et al., 2008).

There are many research studies from the organizational perspectives and much attention has been given to this area since RFID technology is mostly introduced through business organizations, particularly in the early stages of adoption. Many critical issues such as the success or failure of IT adoption are more attractive to observe and this is another reason for many studies in this area. At an organizational level, the behavioral perspectives have also been investigated by many researchers: determinants or factors such as top management support, requirements, trust, organizational innovativeness, and perception of potential are considered (Leimester et al., 2009; Schmitt and Michahelles, 2007; Wen et al., 2004). As RFID adoption at an organizational level should consider technological issues, there is a large number of technology related factors considered in the literature such as compatibility, complexity, industry standards, infrastructure, technological choice, and security (Bhattacharya et al., 2008; Lai et al., 2005; Lin, 2009; Schmitt and Michahelles, 2007 and Wu et al., 2006).

Table I shows the results of this literature study on factors affecting RFID and IT adoption from three levels of analysis: country, industry, and organization levels. In this table, it can be seen that there is a distinct lack of literature at a country level that specifically address issues of RFID. 


\begin{tabular}{|c|c|c|}
\hline Study & Factors & Issues \\
\hline \multicolumn{3}{|c|}{ Country-Level } \\
\hline Corrocher (2002) & $\begin{array}{l}\text { Three stages: Speed (Infrastructure, human resources, competition, } \\
\text { competitiveness); Intensity (market, diffusion); Impact (economic \& social change) }\end{array}$ & $\begin{array}{l}\text { Measuring digital divide (level of } \\
\text { digitalization) }\end{array}$ \\
\hline Dewan et al. (2005) & $\begin{array}{l}\text { Economic (GDP, tech cost), demographic (urban pop.s year schooling), } \\
\text { Environmental (telephone line, trade in goods) }\end{array}$ & $\begin{array}{l}\text { Digital divide (IT penetration per capita and } \\
\text { per GDP) }\end{array}$ \\
\hline Di Gregorio et al. (2005) & $\begin{array}{l}\text { ICT Infrastructure, human capital, } \\
\text { Institutional environment (economic freedom, country risk), path dependence } \\
\text { (historical measures of Internet infrastructure/ Host), Entrepreneurial activity, } \\
\text { Regional differences }\end{array}$ & Drivers of e-business activity \\
\hline $\begin{array}{l}\text { Kauffman \& } \\
\text { Techatassanasoontorn (2005) }\end{array}$ & $\begin{array}{l}\text { Within-country factors (wealth, telecom infrastructure, market competition, access } \\
\text { cost, standards); } \\
\text { Geographical influences (regional \& international influences) }\end{array}$ & $\begin{array}{l}\text { Global digital divide for digital wireless } \\
\text { phone technologies }\end{array}$ \\
\hline Oxley \& Yeung (2001) & $\begin{array}{l}\text { Internet users per capita, internet host per capita, GDP per capita, Rule of law, } \\
\text { credit card per capita, card transaction per capita, infrastructure (PC, internet, } \\
\text { mobile phone) per capita. }\end{array}$ & eCommerce readiness \\
\hline 3Shih et al. (2008) & $\begin{array}{l}\text { Basically three factors: eapital resourees, complementary assets (infrastrueture \& } \\
\text { HR) and openness to external influence. }\end{array}$ & $\begin{array}{l}\text { IT diffusion (measured by IT investments) in } \\
\text { developing countries }\end{array}$ \\
\hline & $\begin{array}{l}\text { Factors: GDP per capita (most), Foreign aid to private, credit \& loan to private, } \\
\text { Share of the economy in information-intensive industries, education, telecom } \\
\text { infrastructure, foreign investment }\end{array}$ & . \\
\hline Zhu \& Kraemer (2005) & $\begin{array}{l}\text { Regulatory support (legal protection, business law, security \& privacy coneerns), } \\
\text { Legal \& institutional framework }\end{array}$ & Post-adoption of e-business \\
\hline \multicolumn{3}{|c|}{$\begin{array}{lll}\text { Industry-Level }\end{array}$} \\
\hline Haghighi et al. (2010) & Competitor, eustomer, technology suppliers & eBanking development \\
\hline Lin (2009) & $\begin{array}{l}\text { Industry standards; government support, cost, technology, infrastrueture, } \\
\text { international standards \& specification, security \& privacy }\end{array}$ & Challenges \& barriers of RFID \\
\hline OECD (2007) & Standards, business benefit, technology level, application stage & Barriers and benefits of RFID \\
\hline Wen et al. (2004) & $\begin{array}{l}\text { Normative factors (industry, trade associations, favorable climate) and coereive } \\
\text { (regulatory pressure, dominating partner pressure). }\end{array}$ & $\begin{array}{l}\text { Environment, organization, technology \& } \\
\text { product (case of RFID adoption by } \\
\text { manufacturing companies in China) }\end{array}$ \\
\hline White ef al. (2008) & Anticipated benefit, anticipated ROI and decision to adopt & Early adopters in SCM \\
\hline \multicolumn{3}{|c|}{ Organization-Level } \\
\hline Bhattacharya et al. (2008) & $\begin{array}{l}\text { Drivers (benefit, mandates, cost, standard etc), } \\
\text { Benefits (better inventory, security, visibility, cost), tech choice, applieations. }\end{array}$ & Drivers and benefits of RFID \\
\hline Lai et al. (2005) & $\begin{array}{l}\text { Opportunities: advance development of industry chain, market size, logistic growth, } \\
\text { manufacturing level and type of application (counterfeit). } \\
\text { Challenges: standards, cost, business environment, business model and nature of } \\
\text { adoption. }\end{array}$ & $\begin{array}{l}\text { Opportunity and challenges (case study of } \\
\text { China) of RFID adoption }\end{array}$ \\
\hline Leimeister et al. (2009) & Experiences, perception of potential and organizational size & $\begin{array}{l}\text { Pereeived strategic importance (cross- } \\
\text { national comparisons) of RFID }\end{array}$ \\
\hline Lin (2009) & $\begin{array}{l}\text { Support for innovation, quality of human capital, organizational knowledge } \\
\text { accumulation, company size. }\end{array}$ & Organizational determinants of RFID \\
\hline Schmitt et al. (2007) & $\begin{array}{l}\text { Compatibility (i.e. technological, hardware, software and data standards), costs, } \\
\text { complexity of the technology, performance (i.e. technological capability and } \\
\text { environmental influences on systems), and top management support }\end{array}$ & $\begin{array}{l}\text { Technological, Environmental and } \\
\text { Organizational (TOE) factors of RFID }\end{array}$ \\
\hline Sharma et al. (2008) & $\begin{array}{l}\text { Inter-organizational pressure, organizational readiness (top management support, IS } \\
\text { infrastrueture \& eapabilities, benefits, standard \& privacy). }\end{array}$ & Adoption and implementation of RFID \\
\hline Wen et al. (2004) & $\begin{array}{l}\text { Mimetic factors (competitive \& status pressure), normative factors (industry, trade } \\
\text { associations, favorable climate) and coercive (regulatory pressure, dominating } \\
\text { partner pressure). }\end{array}$ & $\begin{array}{l}\text { Environment, organization, technology \& } \\
\text { product (case of RFID adoption by } \\
\text { manufacturing eompanies in China) }\end{array}$ \\
\hline White et al. (2008) & $\begin{array}{l}\text { Benefits, ROI, operational deployment, eustomer mandate, } \\
\text { industry sector, organizational innovativeness, level of integration (embedded vs. } \\
\text { slap \& ship) }\end{array}$ & $\begin{array}{l}\text { Suecess and determining factors for early } \\
\text { adopters of RFID in SCM }\end{array}$ \\
\hline Wu et al. (2006) & Technology, standard, patent, cost, infrastructure, ROI, bareode to RFID migration & Challenges to global RFID adoption \\
\hline
\end{tabular}

Table I. Factors affecting RFID adoption at country, industry and organization level. 


\subsection{RFID Adoption in Developing Countries}

As RFID shares many characteristics with other ITs, it was assumed that IT literature on developing countries could assist in locating relevant factors for RFID adoption. Several studies on IT adoption have specifically addressed the issues of developing countries including ICT diffusion (Baliamoune-Lutz, 2003), eBusiness (Di Gregorio et al., 2005), mobile adoption (Kauffman and Techatassanasoontorn, 2005), eCommerce (Molla and Licker, 2005), IT investment (Shih et al. (2007), and the Internet (Wolcott et al., 200I). In terms of macroenvironmental indicators, Baliamoune-Lutz (2003) identified that government trade policies (including liberalization), openness, export-oriented investment, as well as income per capita were the factors that affect IT diffusion in developing countries most. Molla and Licker (2005) reported that eCommerce adoption in developing countries is strongly constrained by infrastructure particularly in terms of quality, availability, and access costs. A low quality of infrastructure often results in a low level of ICT diffusion and low awareness, which is an important factor in achieving critical mass through network externalities. Other issues such as lack of institutional readiness and trust in ICT governance, lack of eCommerce complexity, and lack of adequate resources are other typical issues in developing countries. Bingi et al. (2000) examined the similarities and differences between developed and developing countries with regards to IT adoption: they found that the substitution of labor, quality of infrastructure, and ability to buy IT equipment are main issues in developing countries together with other common factors that are shared with developed countries such as cost justification and national IT priority. The low cost of human resources in developing countries often discourages companies to invest on capital intensive IT. Other leading factors for discouraging IT adoption include lack of IT personnel, information literacy and culture, trade restrictions on hardware/software imports, and less competitive IT business environments (e.g. telecom monopolies).

To discover specific factors influencing RFID adoption in developing countries for each perspective, the fundamental issues of IT adoption in developing countries were reviewed. As mentioned in several studies (BaliamouneLutz, 2003; Bingi et al., 2000; Molla and Licker, 2005; and Walsham et al., 2007), these factors can be summarized into the following areas: IT infrastructure (e.g. lack of quality and access of IT infrastructure), institution (e.g. lack of trust), top management (e.g. perception and support), government policy (e.g. trade, national priority, expenditure, donor dependencies), human resources (e.g. lack of IT personnel, low mobility, low innovation), and economics (e.g. GDP per capita, hard currency, funding, FDI, geographical location, etc.).

\section{Design of A two-dimensional RFID Adoption Framework}

As much literature has discussed RFID adoption and diffusion from different perspectives, there is a challenge to create a framework with a wider perspective for RFID adoption and diffusion. It was observed that there are various perspectives for RFID but there are two that are considered to be the most important: the stages covering the phases of RFID adoption and diffusion, and the scale reflecting the level of analysis of RFID adoption and diffusion from the organization, industry and country levels. With the assumption that any information technology, whether hardware, software or systems, will follow similar patterns of adoption as suggested by much research, particularly Nolan (1973) and Shih (2008), the stages are important to represent the dynamic characteristics of IT adoption along a time domain. In addition, studying different levels of analysis could improve understanding of different coverage of issues, particularly from the perspective of policy makers and decision makers.

\section{I. Stages of Adoption: Preliminary, Intermediate, and Mature Stages}

As explained in the literature, particularly in Corrocher and Ordanini (2002), Chao et al. (2007), Guo and Chen (2007), and White et al. (2002), the adoption and diffusion of any information technologies does not follow a linear path, but rather an S-shaped curve. In this paper, it is considered that RFID adoption and diffusion use the same S-shaped curve and three stages of adoption and diffusion are proposed: preliminary, intermediate, and mature stages. 
a) The preliminary stage refers to the short term orientation of RFID applications which is aimed to ensure nominal compliance with customer's mandates or to provide nominal improvement of the existing processes and services, particularly in public sector. In this stage, RFID is generally a closed loop system which means that it is only applied within an organization or it is applied within limited areas or units inside an organization and does not involve other organizations. The adoption drivers are more coercive as it is imposed by customers or government than when they are imposed by the project owners. Here, the key success factors for RFID adoption and diffusion include customer service levels, infrastructure (IT, logistics, legal systems), investments, priorities of the national sector, inter-organizational pressures, training, and market access.

b) The intermediate stage refers to the conditions when RFID diffusion is accelerated as it achieves critical mass and global standards are accepted. The RFID applications become more business oriented as the organization recognizes tangible economic benefits of RFID, which is applied to improve business operations and services within organizations or supply chains. In this stage, cost reduction of business services and return on investment become more important objectives in adopting RFID. Industry requirements as prescribed by business associations or supply chain members are generally regarded as the primary driver of RFID adoption. Initially, the RFID system being applied is a closed loop, but there is the intention to become an open loop system as process improvement may require integration with other organizations. Here, the key success factors for RFID adoption and diffusion begins to cover customer awareness, global or industry standards, fulfillment infrastructures, which include property rights, and acceptance of the rule of law, market competition, RFID technology compatibility, and the country's IT users. Migration from legacy systems such as existing barcode technology is also another factor that should be considered when promoting applications.

c) The mature stage refers to the application of RFID technologies to create higher value services through business process transformation as business competition becomes the main driver. In this stage, service values and service effectiveness become important objectives to adopt RFID and it is applied to an even broader range of applications inside the organization or with supply chains as RFID becomes a powerful tool in understanding customer demands by collecting low level data from objects. Moreover, its implementation changes into open loop systems as the maximum benefits of the system can only be created through business transformations within organization or along supply chain members. Thus, the key success factors include improved quality of life, rule of law (including privacy and security), business models, technology complexity including organizational capabilities to handle the complexity, and user cultures toward IT.

The stages of RFID adoption are shown as Figure I.

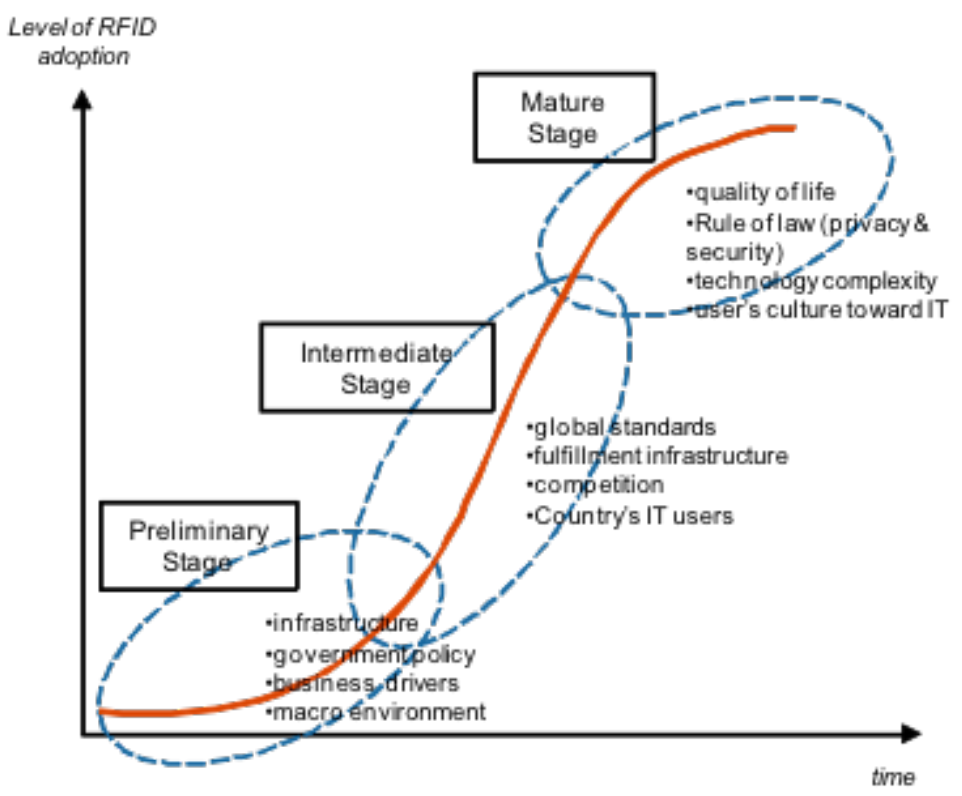

Figure I. Stages of RFID adoption and diffusion 


\subsection{Scale of Adoption: Levels of Analysis of RFID Adoption}

As the level of analysis of RFID adoption and diffusion varies between organizations, industries, and countries, the success factors of RFID adoption and diffusion depend on various conditions that reflect the views of policy or decision makers. In this stage, a set of success factors are proposed for RFID adoption for every level of analysis based on the literature survey conducted previously.

a) At the organizational level, both the infrastructure and people are dominant issues as has been identified by many scholars. The success factors may include top management commitment to run RFID projects, employee training for the new system, employee knowledge, and customer demands. In addition, organizational infrastructure is also important in the success factor as a result of the requirements for compatibility with other technologies, data management, and RFID technology complexity.

b) At the industry level, the sectoral environment is considered a dominant issue and the existence of industry associations, industry standards, industry competition, and market sizes are dominant factors that encourage RFID adoption and diffusion. The influence of other sectors such as logistics growth and R\&D spending are also important factors for adoption at an industry level. Achieving business efficiency is a strong theme in this level; therefore, an organization's short term benefits and supply chain efficiencies are also considered as key factors for RFID adoption at an industry level.

c) At a country level, as much of the literature has already mentioned, the macroeconomic environment is regarded as the dominant success factor for IT adoption including RFID technology. Some examples of macroeconomic factors are international trade volumes, amount of FDI, wealth, and a country's national priority for development. Other important factors for the macroeconomic environment are global standards, infrastructure logistics, and legal systems.

Based on these two perspectives of adoption (stage and scale), a two-dimensional framework for RFID adoption was developed and called the Stage-Scale (2S) Map, which describes the direction of the two perspectives as shown in Figure 2. From the 2S Map, the change of themes from stage perspectives at each level can be observed. For example, the infrastructure and people are the dominant issues in the preliminary stage, but then the issues move to standards and business competition in the intermediate stage, and then to regulation, long term benefits, such as quality of life and service effectiveness, in the mature stage. Successful RFID adoption in developing countries should consider these key issues including the required infrastructures, skilled people, and supporting macroeconomic environment including government support and initiatives. By identifying the factors relevant to the issues for developing countries from Figure 2, it can be observed that most factors in this category are situated along the preliminary stage and some parts of the intermediate stage. Furthermore, in the intermediate stage, the factors affecting RFID adoption are also shared with developed countries. 


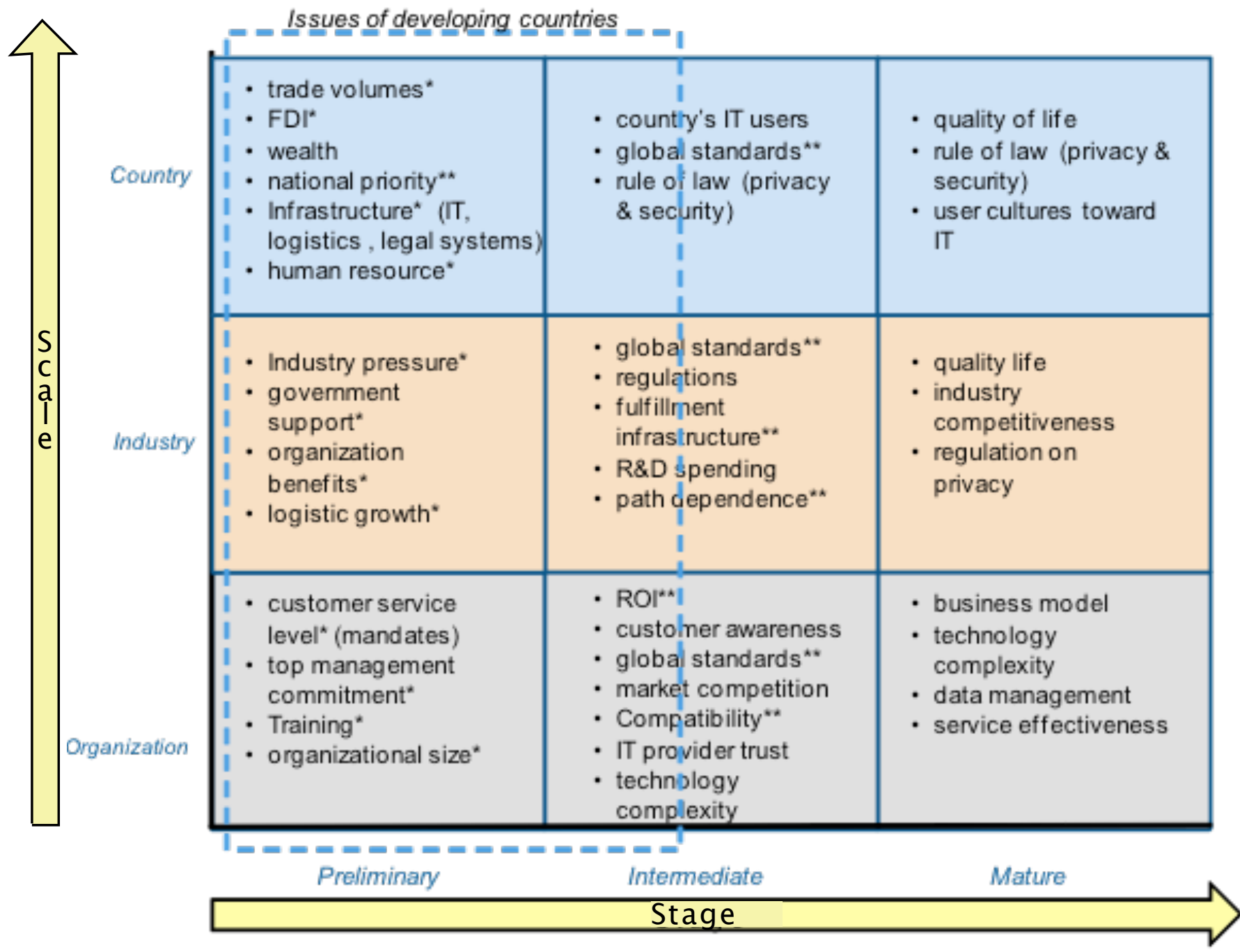

Notes: *) specific issues of developing countries; **) common issues with developed countries

Figure 2. Two-dimensional framework for RFID adoption and diffusion.

\section{Implications and Conclusions}

From the framework shown in Figure 2, the factors related to early stages of RFID adoption are identified and mostly fit with the situation of developing countries; the stage adoption then become more mature as in the intermediate and mature stages, the factors are more closely relevant to the issues faced in developed countries. From the figure, it was identified that at an organizational level, the success factors of RFID adoption in developing countries can include top management commitment, training, and organizational size. While at the industry level, the factors fall within the category of early stages including government support, pressure from industry association, as well as logistics growth. Similarly, at a country level, the following key factors are relevant to developing countries: the existence of infrastructure (including any connectivity infrastructure, logistics, distribution, and fulfillment such as legal systems), the macroeconomic environment (e.g. trade volume with foreign countries, FDI, country's wealth or GDP), the quality of human resources, and government initiatives (e.g. RFID pilot projects, support of microelectronics or components industries, enforcement of the use of RFID such as for public services and security). 
As in Figure 2, the factors common to both developed and developing countries primarily exist in the intermediate stage of RFID adoption and diffusion, such as global standards and compatibility, migration from legacy systems, which are prerequisites for pervasive adoption, and organizational environments that could encourage or discourage RFID implementation such as government regulation on issues such as privacy, safety, security, and counterfeit prevention. Finally, for developed countries, the success factors include quality of life, a country's wealth, industry competitiveness (which could promote RFID adoption at a more advanced level), capability to handle and manage explosive RFID data, privacy regulations, and consumer behavior in accepting RFID. However, it is considered that these findings for both specific and common factors require further validation through research using individual cases in developing countries.

The proposed framework also suffers from limitations as it cannot delineate between factors for developed and developing countries and it is based on a considerable literature gap between the different perspectives. Currently, there is a lack of vigorous approaches available to classify the success factors for developing countries, although there are numerous studies on IT for developing countries. In this report, the classification of success factors belonging to developing countries is based on country specific cases as mentioned in the literature.

Finally, it is concluded that RFID is a promising technology with large potential benefits, and its potential applications have recently begun to garner attention in developing countries. Currently, most literature has discussed RFID adoption from an organizational perspective, but few have directly addressed the issues of developing countries. In this paper, a literature study was conducted on various perspectives of RFID adoption and diffusion to identify the key issues and success factors. There are various perspectives that were observed for RFID adoption and diffusion, but only two were selected in this paper as the most important factors: the stage of adoption and the scale of adoption. This became the foundation for the proposed framework to identify success factors for RFID adoption in developing countries covering key factors from a scale perspective (organization, industry, and country) and stage (initial, intermediate and mature). It was concluded that the framework is very useful to provide a broad view of RFID adoption and to observe the dynamic changes in RFID issues from different perspectives, which is very useful for policy and decision makers. It is also useful to identify the factors of RFID adoption in developing countries, which mostly fall within the preliminary stage, while the factors shared with developed countries are mostly situated in the intermediate stage.

\section{Further Study}

This study also serves as a reminder that there are many gaps in the research on RFID adoption and diffusion. As there is a drawback in the literature, particularly research gaps between developed and developing countries as well as rigorous theories or frameworks for the classification of RFID factors in developing countries, further study is needed to provide stronger foundations for the framework and methodologies to identify and categorize success factors in developing countries. In terms of the scale, specific industry perspectives have received little attention in the literature and few success factors were identified at this level; further study of RFID adoption from an industry perspective is needed. In the same manner, due to abundant literature, country level perspectives are dominated by factors adopted from other ITs such as the Internet, wireless communication, and eCommerce. Although RFID is also an IT as well as a network technology, further study on other ITs that are closely related to RFID (such as barcodes and other identification technologies) may be needed in order to acquire a better understanding about its characteristics. Moreover, further study should be conducted to verify the degree of importance of those success factors since each factor has different degree of urgency compared with other factors; this could be achieved by conducting a survey targeted at experts from different countries. Prioritization methods such as analytical hierarchy processes are suggested as an appropriate tool for this survey. 


\section{About the Authors}

Nyoman Adhiarna received his BS in industrial engineering from Bandung Institute of Technology (ITB), Indonesia and an M.Eng in manufacturing systems engineering from Royal Melbourne Institute of Technology (RMIT), Australia. In endeavor to acquire his $\mathrm{PhD}$, he is currently a research scholar in the Global Information \& Telecommunication Technology Program at the Korea Advanced Institute of Science and Technology (KAIST), Daejeon, Republic of Korea. His research interests focus on RFID applications, IT adoption \& diffusion, IT standardization issues and IT \& telecommunication policy in developing countries. He currently works for DG Spectrum Resources \& ICT Equipment, Ministry of ICT, Indonesia.

Yoon-Min Hwang is a researcher in Auto-ID Lab Korea and $\mathrm{PhD}$ candidate in the Department of Management Science at the Korea Advanced Institute of Science and Technology (KAIST), Daejeon, Republic of Korea. He earned a BS from Department of Management and Economics at the Han Dong Global University, and an MA in IT Business at the Information and Communication University, Daejeon, Republic of Korea. His research interests include innovation by technology like RFID/USN, strategy of supply chain management, and ICT development for country wide.

Jae-Jeung Rho is currently the director of Global Information \& Telecommunication Technology Program and an Associate Professor of Management Science at the Korea Advanced Institute of Science and Technology (KAIST), Daejeon, Republic of Korea. He obtained his BS in mechanical engineering from Seoul National University (SNU) and an $\mathrm{MS}$ and $\mathrm{PhD}$ both in industrial engineering from University of Houston, United States. He is also the director of Business Division in Auto-ID Lab Korea and a committee member of RFID evaluation in the Korea Institute of Science \& Technology (KIST). His teaching and research interests include supply chain management, application of RFID/USN, EPC sensor network and applications of mobile technology in developing countries.

\section{References}

BALIAMOUNE-LUTZ, M. (2003). An analysis of the determinants and effects of ICT diffusion in developing countries. Information Technology for Development, I0(3), pp. I5I-169.

BHATTACHARYA, M., Chu, C. H., Mullen, T. (2008). A Comparative analysis of RFID adoption in retail and manufacturing sectors. 2008 IEEE International Conference on RFID, Las Vegas, Nevada, Pp. 24I-249.

BINGI, P., Leff, L. G., Shipchandler, Z. E., Rao, S. (2000). Critical IT implementation issues in developed and developing countries. Information Strategy: The Executive Journal, I6(2), pp. 25-34.

BROWN, I., Russell, J. (2007). Radio frequency identification technology: an exploratory study on adoption in the South African retail sector. International Journal of Information Management, 27(4), pp.250-265.

CHAO, C. C., Yang, J. M., Jen, W. Y. (2007). Determining technology trends and forecasts of RFID by a historical review and bibliometric analysis from 1991 to 2005. Technovation, 27(5), pp.268-279.

CORROCHER, N., Ordanini, A. (2002). Measuring the digital divide: A framework for analysis of cross-country differences. Journal of Information technology, vol. I7, p.9-19.

DEWAN, S., Ganley, D., Kraemer, K. L. (2005). Across the digital divide a cross-country multi-tech analysis of the determinants of IT penetration. Communication of the Association for Information Systems, 6 (I2), pp. 409-432.

DI GREGORIO, D. Kassicieh, S. K., De Gouvea-Neto, R. (2005). Drivers of e-business activity in developed and emerged markets. IEEE Transaction on Engineering Management, 52 (2), pp. I55-166.

EDWARD, J. (2007). Governments Influence RFID adoption, RFID Journal, November/December.

EDWARD, J. (2009). Public-sector RFID, RFID Journal, July/August.

FISH, L. A., Forrest, W. C. (2006). The 7 success factors of RFID. Supply Chain Management Review, I0(6), pp.26-32. 
GUO, X., Chen, G. (2005). Internet Adoption in China. Communication of the ACM, 48 (4), pp. 54-58.

HAGHIGHI, M. Divandari, A., Keimasi, M. (2010). The Impact of 3D e-readiness on e-banking development in Iran: A fuzzy AHP analysis. Expert Systems with Applications, 37(2010), pp. 4084-4093.

HOSSAIN, M. M., Prybutok, V. R. (2008). Consumer acceptance of RFID technology: an exploratory study. IEEE Transactions on Engineering Management, 55(2), pp.316-328.

HUANG, J. H, Huang, W. W., Zhao, H., Huang, H. (2004). An e-Readiness assessment framework and two field studies. Communication of the Association for Information Systems, 14, pp. 364-386.

IRANI, Z., Gunasekaran, A., Dwivedi, Y.K. (2010). Radio frequency identification technology (RFID): research trends and framework. International Journal of Production Research, 48(9), pp. 2485-25II.

KAUFFMAN, R. J, Techatassanasoontorn, A. (2005). Is there a global digital divide for digital wireless phone technologies? Communication of the Association for Information Systems, 6(I2), Pp. 338-362.

LAI, F., Hutchinson, J., Zhang G. (2005). Radio frequency identification (RFID) in China: opportunities and challenges. International Journal of Retails and Distribution Management, 33 (I5), pp. 832-842.

LEIMEISTER, S., Leimeister, J. M., Knebel, U., Krcmar, H. (2009). A cross-national comparison of perceived strategic importance of RFID for CIOs in Germany and Italy. International Journal of Information Management, 29(I), pp.37-47.

LIN, C. Y. (2009). An empirical study on organizational determinants of RFID adoption in the logistics industry, Journal of Technology Management \& Innovation. 4(I), Pp.I-7. LIN, L. C. (2009). An integrated framework for the development of radio frequency identification technology in the logistics and supply chain management. Computer \& Industrial Engineering, 57(I), pp. 832-842.

MAUGIS, V., Choucri, N., Madnick, S. E., Siegel, M. D., Gillett, S. E., Haghseta, F., Zhu, H., Best, M. L. (2005). Global e-readiness - for what? Readiness for e-banking. Information Technology for Development, II(4), Pp.3I3-342.
MCKAY, Judith; Marshall, Peter; and Prananto, Adi (2000), "Stages of Maturity for E-Business: The SOG-e Model". PACIS 2000 Proceedings. Paper 3.

MOLLA, A., Licker, P. S. (2005). eCommerce adoption in developing countries: A model and instrument, Information \& Management, 42(I ), pp. 877-899.

NOLAN, R. L., Benjamin R. (1973). Managing the computer resource: a stage hypothesis. Communication of the ACM, 16 (7), pp. 399-405.

OECD (2007). RFID implementation in Germany: challenges and benefits. OECD Committee For Information, Computer And Communications Policy, Report.

OXLEY, J. E., Yeung, B. (200I). E-Commerce readiness: Institutional environment and international competitiveness. Journal of International Business Studies, 32(4), pp.705-723.

ROGERS, E. M. (2003). Diffusion of Innovations. New York, NY, The Free Press.

SCHMITT, P., Michahelles, F. (2009). Status of RFID-EPC adoption. Auto-ID Labs White Paper, WP-BIZAPP-048.

SCHMITT, P., Thiesse, F., Fleisch, E. (2007). Adoption and diffusion of RFID technology in the automotive industry. Auto-ID Labs White Pape, WP-BIZAPP-04I.

SHARMA, A., Citurs, A., Konsynski, B. (2007). Strategic and institutional perspectives in the adoption and early integration of radio frequency identification (RFID). Proceedings of the 40th Hawaii International Conference on System Science, IEEE Computer Society.

SHIH, E., Kraemer, K. L., Dedrick, J. (2008). IT diffusion in developing countries. Communications of the ACM, 5I(2), pp.43-48.

SILBERglitT, R., Anton, S. P., Howell, D. R., Wong, A. (2006). The global technology revolution 2020. RAND Corporation.

SLETTEMEÅS, D. (2009). RFID - the "next step" in consumer-product relations or Orwellian nightmare? Challenges for research and policy. Journal of Consumer Policy, 32(3), pp.219-244. 
WALSHAM, G., Robey, D., Sahay, S. (2007). Foreword: special issue on information systems in developing countries. MIS Quarterly, 3I(2), pp. 3I7-326.

WEN, L., Zailani, Z., Fernando, Y. (2009). Determinants of RFID adoption in supply chain among manufacturing companies in China: a discriminant analysis. Journal of Technology Management \& Innovation, 2009, 4(I), pp.22-32.

WHITE, A., Johnson, M., Wilson, H. (2008). RFID in the supply chain: Lessons from European early adopters. International Journal of Physical Distribution \& Logistics Management, 38(2), pp. 88-107.

WOLCOTT, P., Press, L., McHenry, W., Goodman, S., Foster W. (200I). A Framework for assessing the global diffusion of the internet. Communication of the Association for Information Systems, 2(6), Pp.I-50.

WU, N.C., Nystrom, M.A., Lin, T.R., Yu, H. C. (2006). Challenges to global RFID adoption, Technovation, 26(I2). pp.1317-I323.

ZHU, K., Kraemer, K. L. (2005). Post-Adoption Variations in Usage and Value of e-Business by Organizations: Cross-Country Evidence from the Retail Industry. Information Systems Research, 16(I), Pp.61-84. 